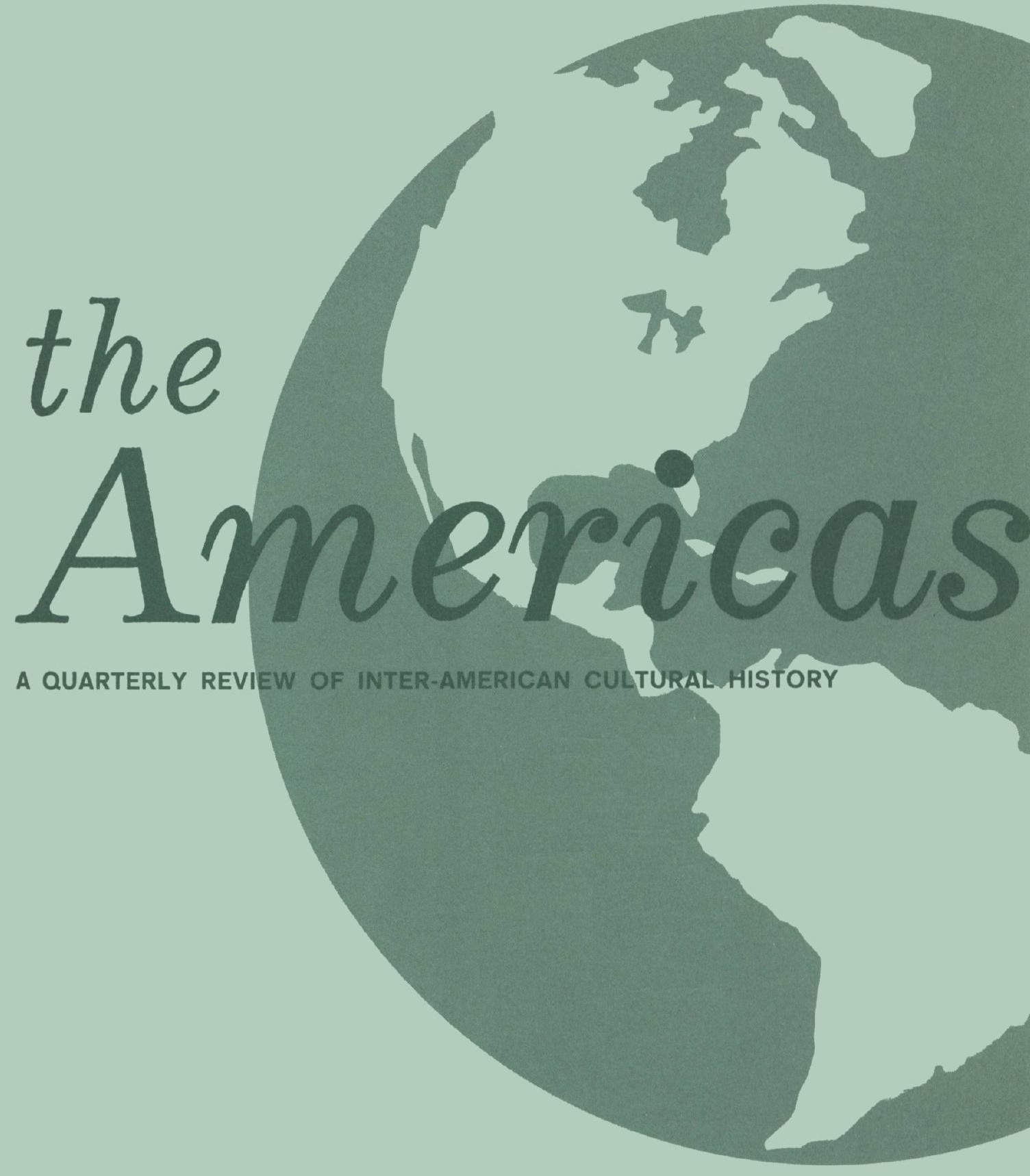

published by the ACADEMY OF AMERICAN FRANCISCAN HISTORY Washington, D.C. 


\title{
EDITORIAL STAFF
}

Editor

Antonine S. Trbesar, O.F.M.

\author{
Senior Assistant Editor \\ James D. Riley \\ Assistant Editors \\ Richard W. Gronet
}

Francisco Morales, O.F.M.

Carol Ann Prebce

\section{AREA EDITORS}

\author{
Robin B. ANDERson \\ University of California-Davis \\ Joseph L. ARBena \\ Clemson University \\ WILLIAM H. BEEZLEY \\ North Carolina State University \\ June E. Hahner \\ State University of New York at Albany \\ Michael T. HamerLY \\ Archivo Historico Del Guayas \\ Kenneth J. Grieb \\ University of Wisconsin-Oshkosh
}

JoHN M. HART

University of Houston

Jaime Rodriguez 0.

University of California, Irvine

Thomas Schoonover

University of Southwestern Louisiana

$$
\begin{aligned}
& \text { William L. Sherman } \\
& \text { University of Nebraska } \\
& \text { JoHN Hoyt Williams } \\
& \text { Indiana State University }
\end{aligned}
$$

\section{SENIOR EDITORS}

\begin{abstract}
DauriL. Alden
University of Washington

Lino G. Canedo, O.F.M.

Washington, D. C.

Donald C. Cutrer

University of New Mexico

Maynard Geiger, O.F.M.

Santa Barbara, California

Richard E. Greenzeaf

Tulane University

Grorge P. Hammond

University of California

Mathias C. Kiemen, O.F.M.

Washington, D. C.
\end{abstract}

†John Tate Lanning

Duke University

Javier Malagón-Barceló

Organization of American States

Michael C. Meyer

The University of Arizona

† John L. Phelan

University of Wisconsin

Fredrick B. PIKe

Notre Dame University

Philip Wayne Powell

University of California at Santa Barbara

France V.SCholes

University of New Mexico 

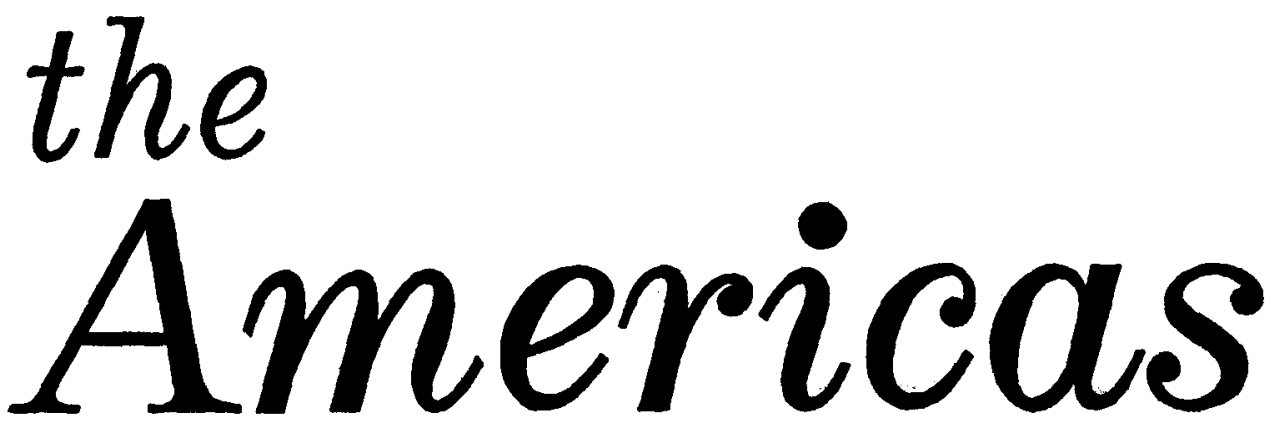

\section{A QUARTERLY REVIEW OF INTER-AMERICAN CULTURAL HISTORY}

Guayaquil Through Independence: Urban Developmenit In A

Colonial System Michael Conniff 385

Narcisco Durán And The Secularization Of The

California Missions

Micbael C. Neri 411

The Construction Of The Interoceanic Railroad Of Guatemala

Delmer G. Ross 430

Sources In lina For The Study Of The Colonial Consulado

of Peru

Lawrence A. Clayton

457

The Catholic Historian In Nineteenth Century Chile

Allen Woll 470

Education In New Granada: Lorenzo María Lieras And The

Colegro Del Espíritu SANTo, 1846-1853

Robert H. Davis 490

The Black Ragamuffins: Racial Hypocrisy In Nineteenth Century

SOUTHERN BRAZIL

Spencer L. Leitman 504

INTER-AMERICAN Notes

Book Reviews

(Listed on following page)

Copyright, 1977

Academy of American Franciscan History

In citing, please use TAm 


\section{BOOK REVIEWS}

Ferdinand Anders: CODEX VATICANUS 3773 (Codex Vaticanus B) Biblioteca Apostolica Vaticana

WAyNe R. RUWET

Kurth Sprague: The Promise Kept.

Dorothy S. GaUS

Richard B. Sheridan: Sugar and Slavery: An Economic History of the British West Indies, 1623-1775

KenNeth J. Grieb

Fernando de Meer: La Cuestión religiosa en las Cortes Constituyentes de la II República Española

James O'Conneli

Mira Wilkins: The Maturing of Multinational Enterprise: American Business Abroad from 1914 to 1970 .

Richard W. Gronet

Jaime E. Rodríguez O.: The Emergence of Spanish America. Vicente Rocafuerte and Spanish Americanism 1808-1832

Frederick B. Pike

Mary W. Helms: Middle America. A Culture History of Heartland and Frontiers.

Alice Littlefield

John S. Brushwood: The Spanish American Novel. A Twentieth-Century

Survey.

Georgette Magassy Dorn

David Rock (Ed.): Argentina In The Twentietb Century.

WARREN SCHIFF

Arnold J. Bauer: Chilean Rural Society From The Spanish Conquest to 1930.

William F. Sater

Olinda Massare de Kostianovsky: La instrucción puiblica en la época colonial.

JohN Hoyt Williams

J. I. Israel: Race, Class and Politics in Colonial Mexico: 1610-1670.

Francisco Morales, O.F.M.

Arturo Warman: ... Y venimos a contradecir. Los campesinos de Morelos y el estado nacional

JAMES M. HART

Michael P. Costeloe: La primera República Federal de Mexico (1824-1835)

(Un estudio de los partidos politicos en el México independiente)

Harold D. Sims

Jean Meyer: La cristiada. Three volumes: La guerra de los cristeros, El conflicto entre la iglesia y el estado, 1926-1929, and Los cristeros . . ...... Wildiam H. BeEzLEY

Scott Cook and Martin Diskin: (Eds.): Markets In Oaxaca. ......... Charles R. BerRY

Irwin Press: Tradition and Adaptation: Life in a Modern Yucatan Maya Village.

Richard Adams

C. Harvey Gardiner: The Japanese and Peru, 1873-1973.

Ronald A. Morse

Noble David Cook (Ed.): Tasa de la visita general de Francisco de Toledo.

Fred BronNER

Lino Gómez Canedo: La provincia franciscana de Santa Cruz de Caracas. Cuerpo

de documentos para su bistoria (1513-1837).

Demetrio Ramos

\section{Published by \\ THE ACADEMY OF AMERICAN FRANCISCAN HISTORY \\ Editor: ANTONine S. TIbesar, O.F.M.}

Editorial and Publication offices: Box 34440, Washington, D. C., 20034. Printed by Capiral. City Press, INc., Montpelier, Vermont 05602. All correspondence and books for review should be sent to the Editor at the editorial office. THE AMERICAS is published quarterly (January, April, July and October). Annual subscription: Pan American countries, direct subscription $\$ 5.00$; United States and other countries, $\$ 12.00$. Current single numbers $\$ 4.00$ each; back numbers $\$ 5.00$ each. Opinions expressed are the responsibility of the contributors. Second-class postage paid at Rockville, Maryland and other post offices. 